\title{
The Regulatory Perception of the Marketing Function: an Interpretation of UK Competition Authority Investigations 1950-2005
}

\author{
by \\ John K. Ashton \\ Norwich Business School and the ESRC Centre for Competition \\ Policy, University of East Anglia \\ \& \\ Andrew D. Pressey \\ Norwich Business School and the ESRC Centre for Competition \\ Policy, University of East Anglia
}

\section{CCP Working Paper 07-1}

\begin{abstract}
This paper explores and quantifies the link between marketing and rulings on competition or antitrust law made by UK competition or antitrust authorities. This examination is timely due to both the changing form and increasing severity of competition law in the UK and the strong associations identified between marketing and antitrust law in the US literature. Through a comprehensive examination of past UK competition rulings from 1950 to 2005, the frequency and content of the principal forms of uncompetitive behaviour during the last half century are recorded. A high proportion of competition law violations are associated with the marketing function. UK competition authorities have viewed specific marketing practices and, more generally, the direction, scope and scale of marketing activity to be causes for concern. We conclude that marketers need to develop a greater awareness of competition law and contribute more to the ongoing discussion as to the present and future form of competition policy.
\end{abstract}

January 2007 
JEL Classification Codes: M31, K21, L42.

Keywords: Marketing, marketing practices, competition law, antitrust law, anticompetitive behaviour.

\section{Acknowledgements:}

We would like to thank Catherine Waddams for helpful comments in the development of this paper. All errors remain the responsibility of the authors. The support of the Economic and Social Research Council is also gratefully acknowledged.

\section{Contact details:}

John Ashton, Norwich Business School and the ESRC Centre for Competition Policy, University of East Anglia, Norwich, NR4 7TJ.

i.ashton@uea.ac.uk

Andrew D. Pressey, Norwich Business School and the ESRC Centre for Competition Policy, University of East Anglia, Norwich, NR4 7TJ.

\section{a.pressey@uea.ac.uk}




\section{Introduction}

The impact of government legislation and policy on the practice of marketing has long been a central element of a marketer's operating environment. It is widely recognised that certain products and services, such as tobacco (Hoek and Sparks 2000), prescription drugs (Sheehan 2003), insurance (McAllister and Erffmeyer, 2003) and food (Caswell et al, 2003) should be advertised, marketed and sold in certain closely controlled ways in order to reduce public harm. In this study, it is proposed that a less discussed form of regulation, competition or antitrust law may present a more fundamental challenge to present marketing conduct and activity in many firms. This proposition is addressed using an assessment of 161 UK competition judgements made over the period 1950-2005.

This examination is timely for many reasons. Firstly, competition or antitrust law concerns both how products are sold and distributed to customers, and how companies collaborate with and serve customers; all are areas for concern in modern marketing. Indeed, Bush and Gelb (2005) indicate marketers may not realise the growing likelihood of violating competition laws. As many business crimes are caused by employees, who often unknowingly break the law pursuing firms' objectives (Le Clair 2000), knowledge of these laws and how they are used is essential for both marketing academics studying, and practitioners in seeking not to violate, such regulations.

Secondly, within our empirical assessment it is apparent that competition law is being applied in the UK with an increasing frequency and with harsher penalties for both individuals and firms. This change, particularly in the level of punishment for competition law violations, heralded by the Competition Act (1998) and the latter Enterprise Act (2002), has been touted as arguably the greatest shift in UK competition policy since the Second World War (Erye and Lodge 2000). Due to the magnitude of this public policy shift, it is important to closely examine this area as major public policy changes have many often unpredictable implications 
for firms, which are often only fully grasped in the medium term (Dobbin and Dowd 1997). While, historically, the assessment of latest developments in competition policy was a prominent topic within the marketing literature (e.g. Engle, 1936, Nystrom 1936, McNair 1938, Edwards 1950), there is little contemporary academic investigation into this issue in the UK. This lack of research, often associated with the changing perception of marketing as being solely an organisational function (Petty 2005), is in stark contrast to the increased role competition issues have within government policy and legislation.

Despite a recent reluctance of marketers to engage in policy discussions (Czinkota 2000), marketers are increasingly confronted by a number of legal and regulatory challenges (Petty 2005). The scope of government policy and law which regulates marketing activity has expanded significantly in most developed nations (Le Clair 2000, Petty 1999, 2005). Indeed, a number of US authors (Le Clair et al 1997, Gundlach and Phillips 2002, Fontenot and Hyman 2004) have recently identified that the form of US antitrust (competition) law presents a significant challenge to forms of marketing. To complement these US investigations, it is pertinent to examine other international examples, such as the UK, as perceived uncompetitive behaviour varies between nations (Aiginger et al 2001). Consequently, a clear assessment and discussion of competition policy is a key issue for both marketing commentators and educators in the UK as well as the USA.

To examine the links between UK competition law and marketing practice, the study is divided into five sections. Following this introduction, the development of competition law in the USA and its adoption in the UK are outlined. In section three, the forms of assessment, data, and characteristics of the competition cases analysed are discussed. A review of the different marketing practices viewed as problematic by the UK competition commissions (the current Competition Commission, and its predecessors, the Monopolies and Restrictive Practices Commission, the Monopolies Commission and Monopolies and 
Mergers Commission) is provided in section four. Within this review the classification of uncompetitive behaviour is presented and the ways in which uncompetitive acts are associated with marketing practices are assessed with reference to individual competition cases. Lastly, in section five conclusions are drawn, suggestions for extending this work are presented and recommendations to develop policy discussions of marketing issues are forwarded.

\section{Antitrust/competition law defined}

Competition law is defined as those policies and actions of the state intended to prevent certain restraints of trade. Competition policy has the function of forming rules for firm conduct and mediating firm excesses, either in the behaviour or the development of firms. This process is undertaken to ensure that the rules by which firms operate should be fair, reasonable, enforceable and generally to protect customers (Stuyck 2005). To achieve these goals, contracts between firms and their customers need to be structured in a manner which prevents abuse of monopoly power. When contractual terms are presented in a form that leads to systematic abuse, misunderstanding or ignorance, this is viewed as an uncompetitive act. If uncompetitive situations are identified, competition authorities intervene to alter these contractual terms and arrangements through structural or behavioural remedies, such as breaking up firms or restricting certain forms of firm conduct. Currently, the belief that unrestricted competition forms an essential element of the modern market economy and promotes efficiency, innovation and economic development (Baer 1996) is widely accepted. Subsequently, over 100 nations have now developed their own antitrust or competition laws, rules and regulations by following the US model of competition law (Djelic 2002).

The development of competition law in the UK, like the USA, has a long history. After 1945 a sizable proportion of UK industry was characterised by 
uncompetitive operating practices (Howard 1950) organised through numerous trade associations. The Monopolies and Restrictive Practices Commission (MRPC) was established, under the Monopolies and Restrictive Practices Control and Enquiry Act (1948), to challenge and amend these restrictive agreements. The MRPC pioneered the UK approach of assessing competition cases using panels of experts to make decisions on competitive arrangements with reference to the perceived public interest. This approach differs from that employed in the USA, where antitrust or competition cases are judged within a court environment by jurors. The UK expert panels, consisting of lawyers, business persons and increasingly academic economists (Wilks 1999), provide lengthy reports on competition cases including a description of the case, suggested remedies to the perceived competition problem and the associated reasoning.

The early cases investigated by the MRPC focused on challenging the uncompetitive practices of trade associations which were generally ordered to cease activities deemed to be against the public interest. Over time, additional competition legislation expanded the form of enquiry to consider the public interest concerns of mergers and situations where dominance or monopoly concerns arose (Monopolies and Mergers Act 1965). The Competition Act (1998) established the Competition Commission as a successor to previous competition authorities. The Competition Commission undertakes inquiries of regulated industries, mergers and markets in response to a request from the Office of Fair Trading, the Secretary of State or another appropriate authority. When uncompetitive behaviours are identified the Commission indicates remedies appropriate to engender competitiveness and customer empowerment. Competition Commission rulings are monitored by the Office of Fair Trading and businesses breaking UK competition law (the Enterprise Act 2002) are liable to fines of $10 \%$ of worldwide turnover and unlimited fines for cartel behaviour. Further, damage claims may be also brought by third parties such as injured competitors against the offending firm(s). Any individual involved in actions 
breaking the Enterprise Act (2002) may be imprisoned for 5 years and disqualified from directorships for 15 years.

\section{Methods for Assessing Competition Judgements}

Most academic research considering the judgements and associated reports made by competition authorities has centred on the economic analysis of firms and markets subject to a competition enquiry. For example much of the UK literature (e.g. Weir 1992, 1993, Davies et al 1999) has questioned why certain judgements have been made through comparison of the final report outcomes. Many of the US studies assessing competition judgements from, for example, the Department of Justice, have extended this form of assessment considering the frequency of different characteristics of antitrust cases over time to ascertain forces which may influence judgements (e.g. Posner 1970, Ghosal and Gallo 2001). This US literature provides a number of insights such as that the frequency of US antitrust cases increases during economic downturns, the limited influence of different political parties, and the importance of generous funding for antitrust bodies (Lewis-Beck 1979). Other assessments of competition authority reports have developed in the marketing literature. These studies have adopted a distinct range of approaches and questions including discussions of the implications of individual competition reports (Ashton and Pressey 2004) or case studies (Bush and Gelb 2005), and assessments of the legal remit (Fontenot and Hyman 2004) or implications of antitrust or competition law.

This study builds on both these academic traditions when assessing UK competition reports. Initially, following Posner (1970) the characteristics of competition cases are quantified, providing a platform from which forms of uncompetitive behaviour and links to marketing practice can be explored. Secondly, the contents of the individual competition reports are examined to assess links between competition law and marketing. This shift from assessing 
only competition report outcomes towards a more grounded approach considering the characteristics and content of rulings, allows the focus and development of competition regulation to be assessed over time (Jennings et al 2005). While the case-by-case approach adopted by the UK competition authorities makes it difficult to draw any clear conclusions (McCorriston and Sheldon, 1997), this systematic review of competition report contents is deemed appropriate. Considering the contents of competition reports, rather than just the reports' decisions, has been advocated by the competition authorities themselves where "... the philosophy of the Monopolies Commission is enshrined in the reports ... You must read these. Each case is different" (past MMC chairman Ashton Roskill (1967) reported in Wilks 1999). From this assessment key areas of concern for marketing practice will be identified, the frequency of these uncompetitive behaviours quantified and any qualitative change over time assessed.

The competition authority reports to be examined were drawn from the 503 competition reports issued over the period 1950-2005 and published by the UK Competition Commission. These reports were produced by the UK Competition Commissions including the current Competition Commission, and its predecessors, the Monopolies and Restrictive Practices Commission, the Monopolies Commission and Monopolies and Mergers Commission (for simplicity hereafter we refer to the Commission). Marketing with this assessment is deemed to be actions recorded as marketing within the reports and as actions which are related to the actions of persons charged with marketing responsibilities. No clear definitions exist to determine which of these competition reports have clear marketing implications and which do not. To overcome this problem, all 161 reports which examine competition within a market are considered. Competition reports which report on mergers, the performance of public utilities, reviews of industry practices or the transfer of ownership of media assets are viewed to be outside the study aims and are not considered. The classification of competition reports used is provided in Table 1. The sample of 
161 market reports are classified in terms of the market size, number of market participants, the geographic focus of activity, the form of industry considered, the reference to marketing in the study and the outcome of the report. These characteristics are reported in Table 2.

The selected competition reports display many changing characteristics. Overall, UK competition cases consider large economic markets, and the size of these markets has increased with time. Most of the earlier competition assessments are concerned with markets for manufactured goods, whilst later cases consider far more service sector markets. These changes reflect wider changes in the UK economy over the sample period. The number of firm participants involved in competition cases has declined over time, reflecting the movement away from investigating trade association. ${ }^{1}$ The geographical orientation of markets assessed has also shifted, with less scrutiny of international markets, and greater appraisal of regional and national markets. The proportion of cases which have made reference to marketing anywhere in the report has declined over time from $86 \%$ of cases in the $1950-55$ period, to just over half of all cases overall (some $57 \%$ ). Cases which explicitly state marketing is an issue in the complaint of uncompetitive behaviour have risen over time accounting for 13 cases in total ( $8 \%$ of all cases). Lastly, the severity of the recommended remedies ${ }^{2}$ for firms has increased over the sample period, demanding both more behavioural changes and more structural remedies, such as breaking up firms. This variable is defined as 'partial behavioural' when only some of the initial complaints are supported by the Commission.

The types of uncompetitive actions recorded in competition reports are classified following a predetermined compendium of behaviours. This definition of

\footnotetext{
${ }^{1}$ We do acknowledge that in a limited number of cases, very large numbers of firms/participants in individual cases have, to a degree, skewed our averages in some periods. For example in the 1950-59 period, the case of the London building market where a very high number of building firms were employing a common pricing regime has inflated our overall estimate somewhat.

${ }^{2}$ For most of the sample period remedies are forwarded by the Commission to an appropriate political figure, the minister, who will then decide if these remedies are to be imposed on the firm(s) concerned or not.
} 
uncompetitive actions is drawn from Competition Commission (2003) and Office of Fair Trading $(2004,2005)$ documentation as to how market competition reports are undertaken and what firm conduct is viewed to be uncompetitive. From this literature six uncompetitive behaviours ${ }^{3}$ are defined:
I. Excessive Prices
II. Price Discrimination
III. Predation
IV. Discounts
V. Vertical Restraints
VI. Refusal to supply and essential facilities.

Table 1

Types of Competition Reports issued in the UK 1950-2005

\begin{tabular}{|c|c|c|c|c|c|c|}
\hline \hline $\begin{array}{c}\text { Time } \\
\text { period }\end{array}$ & $\begin{array}{c}\text { Total } \\
\text { cases }\end{array}$ & Merger & $\begin{array}{c}\text { Market } \\
\text { reports }\end{array}$ & $\begin{array}{c}\text { Transfer of } \\
\text { media } \\
\text { assets }\end{array}$ & $\begin{array}{c}\text { Utilities } \\
\text { and } \\
\text { associated } \\
\text { reports }\end{array}$ & $\begin{array}{c}\text { Review } \\
\text { cases, } \\
\text { other, or } \\
\text { not } \\
\text { undertaken }\end{array}$ \\
\hline $1950-54$ & 9 & 0 & 9 & 0 & 0 & 0 \\
\hline $1955-59$ & 14 & 0 & 12 & 0 & 0 & 2 \\
\hline $1960-64$ & 3 & 0 & 3 & 0 & 0 & 0 \\
\hline $1965-69$ & 29 & 10 & 13 & 2 & 0 & 4 \\
\hline $1970-74$ & 26 & 7 & 12 & 4 & 0 & 3 \\
\hline $1975-79$ & 40 & 14 & 24 & 2 & 0 & 0 \\
\hline $1980-84$ & 60 & 23 & 15 & 6 & 14 & 2 \\
\hline $1985-89$ & 81 & 34 & 24 & 6 & 17 & 0 \\
\hline $1990-94$ & 91 & 45 & 30 & 8 & 8 & 0 \\
\hline $1995-99$ & 75 & 47 & 12 & 6 & 10 & 0 \\
\hline $2000-05$ & 75 & 61 & 7 & 3 & 4 & 0 \\
\hline Overall & 503 & 241 & 161 & 37 & 53 & 11 \\
\hline \hline
\end{tabular}

\footnotetext{
${ }^{3}$ Margin Squeeze might also be a candidate for such a list, although this behaviour was not identified in the sample of 161 competition cases.
} 
Table 2

Characteristics of the sample of Competition Cases

\begin{tabular}{|c|c|c|c|c|c|c|c|}
\hline Time period & 1950-59 & 1960-69 & $1970-79$ & $1980-89$ & 1990-99 & 2000-05 & Overall \\
\hline $\begin{array}{c}\text { Number of Cases } \\
\text { Average market size in } \\
2005 \text { prices (£m) } \\
\text { Average Number of Firms }\end{array}$ & $\begin{array}{c}21 \\
664.92 \\
638.67\end{array}$ & $\begin{array}{c}16 \\
1060.92 \\
245.73 \\
\end{array}$ & $\begin{array}{c}36 \\
1378.92 \\
6.19 \\
\end{array}$ & $\begin{array}{c}39 \\
1966.01 \\
101.64 \\
\end{array}$ & $\begin{array}{c}42 \\
2344.34 \\
30.90 \\
\end{array}$ & $\begin{array}{c}7 \\
20400.97 \\
12.57 \\
\end{array}$ & $\begin{array}{c}161 \\
2450.06 \\
141.69 \\
\end{array}$ \\
\hline $\begin{array}{c}\text { Geographic Focus \% } \\
\text { Regional } \\
\text { National } \\
\text { International }\end{array}$ & $\begin{array}{c}2 \\
4 \\
15 \\
\end{array}$ & $\begin{array}{l}0 \\
9 \\
7\end{array}$ & $\begin{array}{c}0 \\
23 \\
13 \\
\end{array}$ & $\begin{array}{c}3 \\
26 \\
10 \\
\end{array}$ & $\begin{array}{c}5 \\
28 \\
9 \\
\end{array}$ & $\begin{array}{l}1 \\
4 \\
2 \\
\end{array}$ & $\begin{array}{l}11 \\
94 \\
56 \\
\end{array}$ \\
\hline $\begin{array}{c}\text { Type of industry } \\
\text { Manufacturing } \\
\text { Services } \\
\text { Distribution } \\
\text { Primary Production and } \\
\text { Food }\end{array}$ & $\begin{array}{c}18 \\
1 \\
1 \\
1\end{array}$ & $\begin{array}{c}13 \\
1 \\
0 \\
2\end{array}$ & $\begin{array}{c}12 \\
16 \\
3 \\
5\end{array}$ & $\begin{array}{c}13 \\
16 \\
7 \\
3\end{array}$ & $\begin{array}{c}10 \\
21 \\
4 \\
7\end{array}$ & $\begin{array}{l}2 \\
3 \\
0 \\
2\end{array}$ & $\begin{array}{l}68 \\
58 \\
15 \\
\\
20\end{array}$ \\
\hline $\begin{array}{l}\text { No. of Cases Mentioning } \\
\text { Marketing anywhere in the } \\
\text { report ( } \% \text { of cases) } \\
\text { No. of cases where } \\
\text { Marketing is specified in the } \\
\text { complaint } \\
\text { ( } \% \text { of cases) }\end{array}$ & $18(86)$ & $\begin{array}{l}8(50) \\
1(6) \\
\end{array}$ & $\begin{array}{l}24(67) \\
5(14) \\
\end{array}$ & $\begin{array}{l}19(49) \\
6(15) \\
\end{array}$ & $15(36)$ & $\begin{array}{l}7(100) \\
1(14) \\
\end{array}$ & $\begin{array}{l}91(57) \\
13(8) \\
\end{array}$ \\
\hline $\begin{array}{c}\text { Outcome of Competition } \\
\text { Report } \\
\text { None } \\
\text { Partial Behavioural } \\
\text { Complete Behavioural } \\
\text { Structural }\end{array}$ & $\begin{array}{c}3 \\
2 \\
16 \\
0\end{array}$ & $\begin{array}{l}4 \\
3 \\
9 \\
0\end{array}$ & $\begin{array}{c}8 \\
14 \\
14 \\
0\end{array}$ & $\begin{array}{c}8 \\
13 \\
16 \\
2 \\
\end{array}$ & $\begin{array}{c}15 \\
7 \\
15 \\
5\end{array}$ & $\begin{array}{l}1 \\
4 \\
2 \\
0\end{array}$ & $\begin{array}{c}39 \\
43 \\
72 \\
7\end{array}$ \\
\hline
\end{tabular}


Table 3

Frequency of Uncompetitive Behaviours*

\begin{tabular}{|c|c|c|c|c|c|c|c|}
\hline \multicolumn{8}{|c|}{ All Cases } \\
\hline Time period & $\begin{array}{c}1950- \\
59\end{array}$ & $\begin{array}{c}1960- \\
69\end{array}$ & $\begin{array}{c}1970- \\
79\end{array}$ & $\begin{array}{c}1980- \\
89\end{array}$ & $\begin{array}{l}1990- \\
99\end{array}$ & $\begin{array}{l}2000- \\
05\end{array}$ & Overall \\
\hline Excessive Prices & 11 & 9 & 6 & 20 & 17 & 6 & 69 \\
\hline Price Discrimination & 2 & 1 & 2 & 1 & 2 & 2 & 10 \\
\hline Predation & 1 & 0 & 3 & 1 & 0 & 1 & 6 \\
\hline Discounts & 8 & 3 & 8 & 4 & 6 & 3 & 32 \\
\hline Vertical Restraints & 20 & 9 & 24 & 26 & 21 & 6 & 106 \\
\hline Refusal to supply & 4 & 3 & 3 & 3 & 3 & 2 & 18 \\
\hline Number of unique cases* & 21 & 16 & 36 & 39 & 42 & 7 & 161 \\
\hline \multicolumn{8}{|c|}{ Cases NOT Concerning Marketing } \\
\hline Time period & $\begin{array}{c}1950- \\
59\end{array}$ & $\begin{array}{c}1960- \\
69 \\
\end{array}$ & $\begin{array}{c}1970- \\
79 \\
\end{array}$ & $\begin{array}{c}1980- \\
89\end{array}$ & $\begin{array}{l}1990- \\
99\end{array}$ & $\begin{array}{l}2000- \\
05\end{array}$ & Overall \\
\hline Excessive Prices & 0 & 6 & 1 & 7 & 8 & 1 & 23 \\
\hline Price Discrimination & 0 & 0 & 0 & 1 & 1 & 0 & 2 \\
\hline Predation & 0 & 0 & 1 & 0 & 0 & 0 & 1 \\
\hline Discounts & 0 & 1 & 1 & 1 & 2 & 0 & 5 \\
\hline Vertical Restraints & 3 & 6 & 8 & 11 & 12 & 1 & 41 \\
\hline Refusal to supply & 0 & 2 & 1 & 2 & 3 & 0 & 8 \\
\hline \multicolumn{8}{|c|}{ Cases Concerning Marketing } \\
\hline Time period & $\begin{array}{l}1950- \\
59\end{array}$ & $\begin{array}{c}1960- \\
69\end{array}$ & $\begin{array}{l}1970- \\
79\end{array}$ & $\begin{array}{l}1980- \\
89\end{array}$ & $\begin{array}{l}1990- \\
99\end{array}$ & $\begin{array}{l}2000- \\
05\end{array}$ & $\begin{array}{c}\text { Overall } \\
\text { (\%age of behaviour) }\end{array}$ \\
\hline Excessive Prices & 11 & 3 & 5 & 13 & 9 & 5 & $46(67)$ \\
\hline Price Discrimination & 2 & 1 & 2 & 0 & 1 & 2 & $8(80)$ \\
\hline Predation & 1 & 0 & 2 & 1 & 0 & 1 & $5(83)$ \\
\hline Discounts & 8 & 2 & 7 & 3 & 4 & 3 & $27(84)$ \\
\hline Vertical Restraints & 17 & 3 & 16 & 15 & 9 & 5 & $65(61)$ \\
\hline Refusal to supply & 4 & 1 & 2 & 1 & 0 & 2 & $10(56)$ \\
\hline $\begin{array}{c}\text { Number of unique cases } \\
\text { by time period (\%age) }\end{array}$ & $\begin{array}{c}18 \\
(86)\end{array}$ & $8(50)$ & $\begin{array}{c}24 \\
(67)\end{array}$ & $\begin{array}{c}19 \\
(49)\end{array}$ & $\begin{array}{c}15 \\
(36)\end{array}$ & $\begin{array}{c}7 \\
(100) \\
\end{array}$ & $91(57)$ \\
\hline
\end{tabular}

* Multiple behaviours are observed in individual cases.

** Cases counted only once. 
The frequency of these behaviours is reported in Table 3, for a) all market cases, for b) cases where marketing has been reported anywhere in the report, and, c) where marketing has not been referred to anywhere in the report. In many cases multiple forms of uncompetitive behaviour are identified in the competition reports. From Table 3, it is observed that the most frequently observed uncompetitive behaviours are vertical restraints, the use of excessive prices and discounts, with predation occurring only sporadically. Over time, both discounts and vertical restraints display a consistent presence in reported cases and price discrimination is a behaviour which is reported with increasing frequency over time.

For cases where 'marketing' is mentioned anywhere within a competition case, all uncompetitive behaviours are reported with greater frequency, than is the situation when marketing is not mentioned in a report. This indicates that competition cases where marketing is mentioned are more complex cases with potentially more uncompetitive behaviours. Vertical restraints are the most frequently reported uncompetitive behaviour for cases where marketing is mentioned in the competition report.

\section{Analysis}

The assessment of the sample characteristics is extended through the detailed examination of cases which display any of the six identified uncompetitive behaviours. All of the 161 market cases selected are reviewed and the reports or cases with the clearest links between marketing and uncompetitive behaviour are selected and summarised within this review. Details of the cases considered in this discussion are provided in Appendix 1. The key uncompetitive actions perceived by the commission to be associated with marketing are discussed in turn for each of the uncompetitive behaviours. 


\subsection{Excessive Prices}

Excessive pricing concerns the competition commissions when undertaken by a dominant firm, and is considered symptomatic of uncompetitive markets. Excessive prices are identified when prices are higher than might be expected in a competitive market. These judgements are made with reference to similar products in different markets, at different times, by comparison to underlying costs or in earlier cases through the identification of excessive profits. As pricing is a principal marketing function, it is not surprising that in $67 \%$ of cases (46 cases) involving this anticompetitive behaviour, marketing arises as an issue in the competition report. Further, this uncompetitive behaviour has grown in importance for cases which mention the term marketing, or make reference to marketing activities, over the sample period. In most competition cases the incidence of excessive prices has been associated with one of these two marketing concerns, of brand building and how marketing is used to inform consumers, and the appropriate amount of marketing spending.

Initially, the competition commissions have associated the practice of developing a brand through marketing with excessive pricing. Specifically, brand building when used by a dominant firm is considered an uncompetitive restraint on both new entrants to markets and on an appropriate level of price competition. For example, in the investigation of the UK breakfast cereals market (1973) "...advertising and promotion have helped to create and tend to maintain the kind of market in which it is possible for manufacturers to have substantial freedom to determine their prices as they wish" (Breakfast Cereals 1973, para. 88). This view presupposes that dominance by a few firms had reduced price competition to the detriment of consumers. The commission indicated that competition needs to be price driven, as this can be easily matched by competitors. It is reported that this demand for price competition is not welcomed by firms and "this fear [of price competition] is a major factor leading manufacturers to find ways of competing otherwise than in price" (para. 79). Concerns are also raised that a 
"successful advertising campaign" (para. 79) is used by firms in preference to price competition, as competition in advertising is less easy to imitate.

Similar interpretations of brand building have also been provided through other competition judgements. In the Tampons (1980) case, the competition authority argued, "The main difficulties seemed to us to lie on the marketing side and to arise from the unusual degree of brand loyalty and from the limited nature of the market' (para. 2.21). The investigation of the UK grocery market (Supermarkets 2000), raised concerns that price-setting of own-label product lines (termed umbrella pricing), changed relative to branded equivalents rather than costs. This practice has wider implications where, "In this situation, the price of the branded product is allowed to set an upper limit for the entire product group, including own-label lines" (Supermarkets 2000, para. 2.414) leading to excessive pricing.

The function of marketing was also considered in the investigation of UK business banking services (SME Banking 2002) where excessive pricing was identified. Throughout this report the two concepts of 'advertising' and 'marketing' are used interchangeably, where, "...in general the main impact of marketing is likely to lie in promoting and maintaining the name of one bank as against others..." (SME Banking 2002, para. 2.296). Further, the competition authority reported that a reputation is not produced by marketing yet, "...is actually created by being knowledgeable etc, it being unlikely that marketing could do much to create such an asset in the absence of such expertise" (para. 2.253). Therefore, being knowledgeable, competent, trustworthy and creditworthy must exist before "...marketing can have any significant value" (para. 2.253). Consequently, marketing expenditure is "treated as a revenue cost" (para. 2.253) rather than an investment, as reputation is derived from activities performed by non-marketing firm functions. In this light, the role of marketing is limited to maintaining recognition of the positive market attributes of banks, which constitute the real assets of the bank, rather than in creating awareness of them. 
Two concerns exist in the cases involving excessive pricing: one, the role played by marketing in maintaining dominant and highly differentiated brands; and two, the wider rationale for marketing. Initially, anticompetitive concerns arise where a marketing strategy, particularly by dominant firms, does not rely on price and customer offerings are differentiated by dominant market participants. The main competitive concerns occur when low levels of customer price sensitivity exist and customers rely on brands to inform their choices. For example, in the case of the UK breakfast cereals market (1973), it was concluded that the dominant firm, Kellogg's, did not operate against the public interest, rather, Kellogg's might potentially operate against the public interest at some future point. This led to the commission introducing the 'remedy' “...that Kellogg's profit rates should be kept under review and that Kellogg should be required to seek Government approval before making any increase in the prices of its breakfast cereals" (Breakfast Cereals 1973, para. 102). In this regard, there is a schism between the marketing perspective that effective branding recognises that some brands will attract premium prices, and the commission view that branding is used to provide firms with more defensible products that potentially damage competition.

\subsection{Price Discrimination}

Price discrimination emerges when a firm applies different conditions to similar transactions for different customers, or charges different customers the same for goods or services of differing quality or cost. Ten investigations of price discrimination have been undertaken by the commission with marketing featuring as an issue in eight of these cases. For price discrimination to become enforceable an effective form of market segmentation and restriction on re-sale must be present. Price discrimination becomes an uncompetitive act when used by a dominant firm to exclude competition. Marketing concerns in price discrimination cases include offering 'special' price terms to different types of customer, excessive levels of marketing spending, discounting, discriminatory 
price structures for complimentary products, and the use of these pricing structures to recover marketing costs. The link between marketing behaviour and price discrimination was explicit only in a small number of reports with price discrimination viewed as a discriminatory practice adopted by firms "when marketing their products" (Video games 1995, para. 2.67).

Discriminatory pricing structures have also been used to recover marketing spending, for complimentary goods or across a product range. In the report on the supply of video games by Nintendo and Sega (Video Games 1995) it was reported that both firms employed "a discriminatory price structure for software and hardware which operates against the public interest" (para. 2.23). The commission observed Nintendo and Sega had "both been able, when marketing their products in the UK, to set a price structure which achieves higher margins on software than hardware" (para. 2.67). This resulted in a gradual increase in the price of software, which had restricted use to one form of game system or hardware. Concurrently, these firms lowered the prices charged for hardware in order "to make it more difficult for new hardware products to enter the markef" (para. 2.67). These practices increased the total cost of game play for customers and were viewed to be a discriminatory pricing policy used to exploit the firms' market power. Additionally, it was noted that "well over half the overheads allocated are in respect of hardware development and marketing. If these were excluded the margin would be over 50 per cent' (para. 2.92). These costs were allotted to software rather than hardware to artificially lower the relative costs of hardware, and increase software costs, thereby "raising the total cost of game play to consumers over the total period they use the system" (para. 2.94). To amend for this situation, the commission ruled that, wherever possible, costs should be allocated and recovered "on the products on which they were incurred" (para. 2.94).

Overall, the price discrimination cases which are associated with marketing, view pricing policies as potentially uncompetitive when they are undertaken by 
dominant firms. Further, the allocation of marketing costs through discriminatory pricing, to products other than those directly incurring these costs is also viewed adversely.

\subsection{Predation}

When a firm acts in a predatory manner it deliberately incurs losses on the sale of a good or service to eliminate a competitor. Six investigations of predation have been undertaken by the commission with marketing featuring as an issue in five of these cases. This form of behaviour is identified in a number of ways, including pricing at below cost, and displaying intentions to eliminate competitors. While practices such as loss leading, short run promotions and establishing sufficient market share are acceptable for most firms, these actions can be considered uncompetitive when they are undertaken by a dominant firm. A variety of marketing-related motivations exist for predation and selling products below cost (Gundlach 1996). Firms might sell products below cost because of strategic objectives that focus on volume sales (Urbany and Dickson 1994) or retention of valued customers (Blattberg and Deighton 1991).

An example of predatory pricing is provided by the investigation of the UK grocery market (Supermarkets 2000). This case identified the practice of "persistently selling some frequently purchased products below cost" (para. 1.6). ${ }^{4}$ While this form of predation benefits some low-income customers through the provision of more affordable products, this is viewed to damage smaller competitors, potentially reducing customer choice. A further competition concern has been the cross-subsidy from higher-margin items to loss-making products, required by such a predation practice. This activity is considered to lead to a "misallocation of resources and a distortion of competition in the grocery markef" (para. 2.381).

\footnotetext{
${ }^{4}$ In addition to the practices of 'umbrella pricing' and 'price flexing' discussed in previous sections.
} 
No direct link was made between predation and marketing actions by the Competition Commission within the sample cases considered. This said, several major retailers suggested that "market pricing or promotions", "in response to a market-led pricing policy" developing from "competitive pricing pressure" (para. 2.379) could be incorrectly viewed to be predatory actions.

\subsection{Discounts}

While offering discounts is a central element of price competition in many markets (Dolan 1987) the use of discounts under certain circumstances can be considered uncompetitive both for the market and the perpetrator. Of the 32 cases of uncompetitive discounts undertaken by commission, marketing is mentioned in 27 cases. An uncompetitive use of discounts would involve a dominant firm offering discounts in a manner that harms current and future competition in a market. Many forms of discounting, such as volume and loyalty discounts, are used for a variety of motivations. Indeed, discounts or rebates are a marketing "fact of life" and constitute an important part of a firm's marketing strategy (Rao 1980). Consequently, consumers often expect discounts when buying in a larger quantity or for greater package sizes, in return for loyalty, or because of the buyer's status (Nason and Della Bitta 1983, Wilcox et al 1987). The uncompetitive discounting practices identified include quantity discounts, loyalty discounts, discounts for prompt payment, compliance discounts, ${ }^{5}$ and discounts for meeting pre-determined sales targets.

The link between marketing behaviour and discounts was explicit in several reports. For example, discounts were used in "the marketing of sisal and manila fibres" (Hard Fibre Cordage 1956, para. 289), or considered to be a "marketing

\footnotetext{
${ }^{5}$ Discounts to retailers who comply with specified arrangements for stocking, promoting or displaying manufacturer's goods.
} 
weapon" (Frozen Foodstuffs 1976, para. 283). In other cases the link to marketing was implicit and the practice of discounting identified as "special discounts" for loyalty (Copper Products 1955, para. 108), or in return for compliance with certain conditions (Frozen Foods 1976), such as agreeing to stock all or part of a range of products in order to "promote the distribution of ... brands" (Tambrands 1996, para. 1.7).

In the Hard Fibre Cordage (1956) case, discounts were offered as part of an exclusive buying arrangement. Eligibility for this discount, however, was entirely dependent on membership of a particular association of dealers. The commission considered this behaviour hampered market competition and operated against the public interest, noting "...we think it undesirable that the manufacturers should collectively agree to allow uniform rates of discount to listed dealers whom they select as eligible and only to those dealers" (para. 292). The role played by marketing in this practice was explicitly recognised, where marketing practices, 'lock in' customers, reducing the ease with which a customer can switch supplier, thereby restricting competition. Consequently the commission noted, "... the marketing of sisal and manila fibres is so organised at present as to render speculative buying and reselling very difficult"' (para. 289).

Although not explicitly identifying marketing behaviour, other cases (e.g. Copper Products 1955), have based eligibility for discounts on membership to certain associations, volume of sales and customer loyalty. These practices were viewed to be harmful to competition as they impede market access by independent producers. Consequently, for the case of Copper Products (1955), these discounts were considered "...an inducement to the customer to place all his business with members of the association and discourages him from placing any of his business with non-member concerns" (Copper Products 1955, para. 104).

In other instances, compliance discounting has been employed to encourage retailers to stock certain manufacturers' products. In the case of a frozen food 
supplier (Frozen Foodstuffs 1976) the commission found discounts were paid retrospectively to some retailers in order to encourage retailers to stock certain products. This behaviour was considered part of the "marketing strategy of the need to secure a satisfactory share of the limited capacity of refrigerated cabinets in retail stores" (para. 299) by major suppliers in the market. While the commission accepted that these discounting practices were strongly influenced by the bargaining power of the major retailers they recommended that suppliers "should be required to abandon its practice of granting discounts to retailers for the allocation by the latter of space in their freezer cabinets" (para. 342) and that other competitors should also abandon such practices. Similar discounting practices were also observed in the Tambrands (1996) case where discounts were made to retailers which stocked a full product range. Although not explicitly linked to marketing action these discounting practices were considered a function of the 'promotional activities', where the firm's "intention in pursuing the course of conduct is to facilitate negotiations with retailers and to promote the distribution of its brands" (para. 1.7).

The main concerns which emerge from examining cases of discounting and marketing is the use of discounts to exclude competitors from a market and the associated reduction in consumer choice. While it is acknowledged by the commission that the use of discounts by firms is a key marketing practice, this practice is viewed to operate against the public interest when undertaken by dominant firms and to achieve uncompetitive outcomes.

\subsection{Vertical restraints}

This section considers the importance of vertical restraints as an uncompetitive behaviour associated with marketing practice. One hundred and six investigations of vertical restraints have been undertaken by commission with marketing featuring as an issue in sixty-five of these cases. Vertical restraints 
have also been consistently important throughout the sample period for cases which mention marketing. Vertical restraints include the set of business to business and business to customer relationships which impose certain restrictions on the sale and supply of goods and services. If these restrictions are used by a dominant firm to limit present or future competition, an uncompetitive action is identified. Obtaining information on practices involving vertical restraints, however, is problematical as negotiations between firms usually occur in private. Indeed examining competition judgements is one of the few ways to assess the occurrence and prevalence of vertical restraints (McCorriston and Sheldon 1997).

The association between vertical restraints and marketing rests on the need to build relationships with suppliers and customers, a strategy widely recommended throughout the contemporary marketing literature. Strategies of relationship marketing or 'co-opetition', the simultaneous cooperation and competition between organisations (Sharma 2002), are widely advocated as they are hard for competitors to imitate or displace (Day 2000). Indeed, relationships with suppliers have been mooted as an effective method of reducing the impact of competition on an industry (Sheth and Sharma 1996). The negative feature of such forms of relationship building in marketing is the ability of a relatively powerful partner behaving in an opportunistic manner (Fitchett and McDonagh 2000).

The key processes through which vertical restraints develop include the use of trade associations, vertically integrated firms, material and financial incentives, after-sales environment and product specification concerns to provide exclusivity in the sale and purchase of goods and services, and the 'indoctrination' of market participants. The threat of withdrawn supply, which has also been employed to effect vertical restraints, is discussed in greater detail in the next section. Vertical restraints are also associated with a wide range of other competitive behaviours. Indeed, the presence of other uncompetitive behaviours has been attributed to vertical restraints in many cases associated with the marketing function. Uncompetitive behaviours which have developed from the presence of vertical 
restraints have included discounting (Foreign Holidays 1986), pricing (Medical Gases 1956, Foreign Holidays 1986), the bundling of goods (Foreign Holidays 1997), and the common funding of marketing initiatives (Supermarkets 2000). These processes in effecting vertical restraints and related uncompetitive actions associated with marketing are discussed in turn.

During the 1950s, the commission identified the use of vertical restraints with trade associations. In particular, concerns arose within three reports (Dental Goods 1950, Linoleum 1956, and Hard Fibre Cordage 1956), where trade associations were seen to play a central role in maintaining the conditions of supply in their respective industries. For example, in the supply of linoleum floor coverings (1956), "marketing practices" (para. 186) enforced via a manufacturers' association were investigated. These uncompetitive marketing actions developed from the vertical restraint or relationship between the manufacturers' association and their distributors of linoleum. This association promoted practices including maintaining minimum prices, prescribing preferential terms to approved buyers, providing discounts only to wholesalers who buy linoleum from LMA members and imposing restrictions on advertising and exhibiting; all means of controlling supply in the reference market.

The relationships between manufacturers and distributors belonging to a single vertically integrated firm have undertaken branding decisions viewed to be uncompetitive. In the case of Foreign Holidays (1997), the competition authorities indicated that the practice of vertically integrated travel companies, distinctly branding the tour operator and the travel agent, was misleading for consumers. This practice engendered both confusing pricing policies and common discounting policies; actions considered to be contrary to the public interest. This finding is unsurprising as vertically integrated businesses emerged in this industry after a previous competition report (Foreign Holidays 1986) criticised the use of vertical restraints between then separately-owned agents and operators. In conclusion, the Foreign Holidays (1997) report indicated that re-branding 
should be undertaken to reflect the common ownership of vertically integrated firms.

Another process which enables vertical restraints to form between a dominant supplier and distributors is the demand that an independent distributor accepts goods and services exclusively. This exclusive agreement arises for a variety of reasons including the payment of discounts or other financial or material special terms, and 'marketing and indoctrination' (Petroleum Gas 1981, para. 6.53). This form of vertical restraint agreement has been reported (Petrol 1965, 1979; Electric Lamps 1952, 1968; Ice Cream 1979, 2000) repeatedly in a number of industries over the sample period. Within the Ice Cream cases, the dominant manufacturers developed exclusive distribution of their products through the supply of freezer units within which their products might be stored. The supply of freezers was viewed to be a clear material benefit for many of the often small scale retailers. This system was viewed initially as an uncompetitive practice enforced through the firms' "marketing muscle" (1979, para. 310). Later reports viewed this system as inhibiting competition, even if this practice was viewed not to be operating against the public interest.

Examples of exclusive supply encouraged through financial incentive have been observed in the Petrol $(1965,1979)$ and Carbonated Drinks (1991) industries. In the petrol case, retailers choose to both exhibit the brand of a petrol supplier and agree "to sell that supplier brand of petrol exclusively" (para. 82) for receipt of a rebate on the price of supplied petrol. This system termed the "Solus marketing system" (para. 59) operated nationally in the UK. The major petrol suppliers supported this system as they deemed "... their own advantage lies in the direction of making and marketing their own brands" (para. 392). The commission ruled that such an exclusive system of supply must be limited in terms of duration and become easier to terminate. 
A similar system of vertical restraints also developed in the distribution of Carbonated Drinks (1991). The main suppliers to this market required the exclusive distribution of their products for the receipt of special terms from distributors. This practice was viewed to limit choice and lead to higher prices, and further, "... the strength of the brands owned or franchised by the existing bottlers and especially the two main players is the main barrier to the entry of new rivals in this market' (para. 10.50).

Lastly, exclusive supply was viewed to emerge in one case as the outcome of the 'indoctrination' of market participants, in the investigation of the supply of Petroleum Gas (1981) and the exclusivity arrangements of one dominant supplier (Calor). In this case, the commission were concerned that Calor's "power of marketing and indoctrination of the...markef" (para. 6.53), developed from "marketing policies" (para. 6.56), prohibited market entry by new suppliers and might restrict consumer choice. The commission deemed this form of exclusive supply did not operate against the public interest.

The third process through which vertical restraints emerge and uncompetitive marketing actions are recorded lies in the exclusive purchase of goods and services by a dominant firm from suppliers. Cases where this form of vertical restraint have occurred emphasised branding (Car Parts 1982), product specification (Domestic Gas Appliances 1980), contributions from suppliers for marketing initiatives and preferential retailing positioning (Supermarkets 2000).

The importance of branding concerns in the exclusive purchase of goods is illustrated in the investigation of the UK car parts market (1982). In this case the commission noted that car manufacturers' insisted "on the use of their brand names" (para. 4.50) on components, rather than the brand of specialist component manufacturers. This practice was employed with "the purpose of branding car parts...to ensure exclusivity" (para. 4.48), and resulted in their reputation in the market being obscured. Further it was noted that "the 
advertising policy of some car manufacturers and importers" led to the "strengthening of exclusivity" (para. 4.57), whereby manufacturers "emphasise the importance of buying their own branded parts" of components as 'genuine' parts and sometimes implying that alternative parts are unauthorised copies (para. 4.57). This was viewed by specialist component manufacturers as a mechanism to keep them out of the market and to maintain exclusivity of supply.

Exclusivity was also enforced through the demand for products of very particular specifications. When investigating the supply of Domestic Gas Appliances (1980) the competition authorities examined allegations that the British Gas Corporation (BGC) exerted excessive control over the gas appliance retail market to final customers. This investigation focused on BGC's marketing strategies and its behaviour towards gas appliance manufacturers and independent retailers. The commission observed that "The Corporation is, in its capacity as dominant retailer, the principal arbiter of the models to be offered to the public. We find that the manufacturers of appliances are unduly subservient to the Corporation in that their designs give undue weight to the Corporation's views of the marketability of certain characteristics" (para. 13.76). The manufacturers were considered to be "so heavily dependent on the Corporation's marketing of their appliances that a change of its marketing policy has serious effects on their whole prospects" (para. 13.76), including the Corporation "putting strong and largely successful pressure on manufacturers to increase the differentials between their prices to $B G C$ and to other retailers" (para. 13.54) and informing manufacturers in some regions "that it would be against their interests to deal with independent retailers" (para. 13.55). The commission concluded that if BGC treated its competitor distributors "as allies by encouraging their participation in the industry" (para. 13.79), then the industry would have benefited as a whole.

The final process driving vertical restraints observed to have substantial links with marketing practice relates to major supermarkets' relationships with their suppliers. In the report of the supply of groceries from UK supermarkets 
(Supermarkets 2000), the commission indicated that the financial demands made by major supermarkets for the in-store promotion of their products were of particular concern. This practice, carried out to support supermarket's "marketing initiatives", and referred to as "pay to play" costs, was either solicited on an adhoc basis or else was expected in the form of a quarterly advertising and promotion payment (para. 2.479). This behaviour was viewed to adversely affect the competitiveness of some suppliers and competition between suppliers.

From the three forms of vertical restraint examined, trade associations, vertically integrated firms and dominant firms a range of conclusions can be drawn. The outcome of trade association cases was a wider acknowledgment that restrictions should not be imposed on distributors by trade or industry associations. Consequently, vertical restraints in most subsequent UK competition cases have been associated with actions of a dominant firm. From the cases examining vertical restraints within an integrated and dominant firm, cases which involve marketing actions appear difficult for competition authorities to confront and eradicate. This is evidenced in the number of competition investigations undertaken repeatedly in the same industry. More broadly, concerns have arisen that development of brands, the promotion of exclusive supply and payments to promote products produced by other firms, act as vertical restraints.

\subsection{Refusal to Supply and Essential Facilities}

Another form of uncompetitive behaviour, which also often develops from vertical restraints or relationships formed between firms, are limits on, or a refusal to supply, certain customers. Eighteen investigations of refusal to supply or limits on supply have been undertaken by the commission with marketing featuring as an issue in ten of these cases. While a firm generally has the right to choose with whom it undertakes transactions, this freedom is subject to a competition law 
qualification. Refusal to supply becomes an uncompetitive act when a dominant firm refuses to supply a product in a manner which leads to an uncompetitive outcome. Within marketing this form of behaviour arises for many reasons (Lovelock 1991, Good and Evans 2001) such as disciplining price-cutting retailers or avoiding supplying a bad risk customer (Howe 1979). Within UK competition cases the rationale for restricting supply emphasises the requirements to build brands and the need for after-sales services.

One distinctive marketing issue arising from the vertical restraints cases is the practice of selective distribution in order to maintain brand image. In the Fine Fragrances (1993) case, the practice of supplying products only to those retailers which provided "an ambience which accords with the luxury image of the products" (para. 1.2) was deemed a form of selective distribution. This strategy adopted by the fragrance houses was recognised as important to maintain a prestigious brand image, where "Fragrances are products bought by consumers for reasons going beyond the strict function of the product. It appears to be the general view that consumers can be induced to try a particular fine fragrance brand as much for the sake of its image as for the scent' (para. 3.11). Consequently "... for the fragrance supplier, branding is thus a major source of added value" (para. 3.53). It was accepted by the commission that the fine fragrance business places competitive emphasis on non-price factors, and selective distribution was not deemed to be against the public interest.

A second rationale for selective distribution and limiting supply has been the importance of supplying a certain quality of after-sales services and associated sales environment. This situation arose in the New Cars $(1992,2000)$ cases, where the process of exclusive car sales through established chains of car dealerships linked to certain suppliers was examined. In support of exclusive supply to certain car dealerships the car manufacturers maintained that "a motor vehicle is a sophisticated mechanism which requires more after-sales support than other consumer durables and that its marketing must have regard to 
customer expectations, particularly where quality and safety are concerned' (para. 5.5). With such large capital investments made by both car manufacturers and dealerships, exclusive supply was perceived as being an "... essential part of the complete package which is designed to give a high standard of service to the motorist at a reasonable profit' (para. 5.5).

Despite these broadly favourable judgements, equally negative outcomes have followed other similar examinations. In the case of a high quality bicycle manufacturer (Bicycles 1981) the firm, Raleigh, withheld supplies from discount retailers who were, in their judgement, not able to offer a high standard of pre- or post-sales service. The commission ruled "Raleigh's policy of withholding supplies from some retailers therefore had, or was likely to have, the effect of restricting competition in the retailing of Raleigh bicycles" (para. 6.6). It was recommended that Raleigh make a low price version of their bicycles, under alternative brand names to be made available to discount retailers. The commission indicated "...if Raleigh were to supply bicycles to such discount stores under brand names other than Raleigh (in the same way as it now supplies catalogue mail order houses), we believe that any risk of damage to Raleigh's reputation and brand image would be substantially eliminated" (para. 6.29). Such a judgment was particularly striking as this firm was making losses, suffering a substantial decline in market share, and operating in an acknowledged competitive industry. In this case, the emphasis was placed on the perceived uncompetitive nature of the firms' marketing policy, rather than the competitiveness of the market within which the product was sold. ${ }^{6}$

Similar adverse conclusions were also drawn in other supply refusal cases. Black and Decker (1989), a major supplier of electrical power tools, was investigated for withholding supplies to retailers selling below a minimum margin. Similarly, although Black and Decker was a market leader, its market share had been declining sharply. In their judgement, the commission stated: "There is ... a public

${ }^{6}$ See Kay and Sharpe (1982) for a detailed discussion of this case. 
interest in maintaining and enhancing a competitive and innovative retail environment which provides the consumer with service and a wide choice of goods at reasonable prices" (para. 6.62). Similar concerns have also been raised in the supply of domestic electrical goods (Domestic Electrical Goods I and II 1997), which reached similar adverse decisions.

In summary, cases of supply refusal have been typified by the variety of recommendations reached by the commission towards such activities. In some cases, the importance of building brands or providing an appropriate sales service are recognised to be central features of some businesses and the action of supply restriction or refusal treated as a necessary, if unwelcome, action. Conversely, other cases reject this explanation of brand building or provision of higher quality sales service, and recommend that these practices be altered, despite the underlying competitiveness of the market considered.

\section{Conclusions}

This examination develops the previous academic literature on marketing and competition law (Gundlach and Phillips 2002, Le Clair 2000, Bush and Gelb 2005) by extending and generalising arguments developed in the US context within a distinct national environment. Within the conclusions, the wide range of issues emerging from this study will be discussed. The implications of these findings for marketing are then outlined and centre on how marketers can adopt behaviours to reduce their exposure to adverse judgements and to increasingly engage in greater dialogue with policy makers. Lastly, suggestions for further research in this area will be provided.

Within this study, it has been demonstrated that the size, number and severity of UK competition judgements has increased over the sample period 1950-2005. While there has been a slight decline in the number of competition rulings which 
have drawn attention to marketing practices, the majority (57\%) of competition cases have made reference to the role of marketing in uncompetitive behaviour.

From the assessment of individual competition reports, many marketing practices and actions are viewed to be of specific concern. First of all, the use of marketing to build brands is seen to be very problematic. This action has been criticised for both providing barriers to entry in markets, leading to excessive prices, vertical restraints and unnecessary expenditure on marketing itself. Further the use of brands has also been criticised, irrespective of the underlying competitiveness of the reference market, due to perceived views of the role of brands. For example branding is criticised for its potential to restrict supply in some markets. Second, the UK competition authorities' consistently view marketing as a function which should be restricted to supplying product and service information. It is claimed that marketing has the obligation to inform consumers, and actions beyond this activity result in excessive marketing expenditure. When marketing actions are viewed to lead to outcomes other than informing consumers, these actions have been viewed with suspicion and often adversely in UK competition cases. Third, the allocation of marketing expenditures across related goods or services is an action persistently criticised as uncompetitive, be this a function of pricing or a vertical restraint. The UK competition authorities have repeatedly stated that prices for products and services should be closely associated with the costs of production of that product or service. Fourth, assumptions as to how marketing should be undertaken within firms rest on a particular theoretical conception of firm behaviour adopted by the UK competition authorities. When marketing outcomes do not match those expectations adopted by competition authorities, claims of unnecessary and excessive marketing spending have been raised. Fifth, many of the practices we have observed, such as vertical restraints, appear to be difficult to eradicate. In these cases, either the uncompetitive actions are central to the firms' existing business model or different generations of marketers lack a familiarity with the law pertaining to such actions. Last of all, the outcomes from many of the reports are not consistent either over time or even within 
industries. This lack of consistency in judgements raises substantial concerns as to how recent and stronger competition law in the UK is employed by UK competition authorities.

In light of our findings there are many actions marketing managers may undertake. Initially, marketing managers need to be cognisant of competition law. If a marketer is uninformed of competition law they may unwittingly and unknowingly fall foul of such law and guidelines. This position is compounded as marketing by its nature has developed a 'boundary-spanning role' in many organisations, as marketing managers become increasingly involved in a diversity of company functions (Wilkie and Moore 1999). This position provides marketing managers with "ample opportunity to engage in guideline-relevant offences such as price fixing, bribery, fraud and discrimination" (Le Clair et al 1997). Consequently, marketing objectives should be created that are cognisant of the rules for competitive behaviour (Le Clair 2000) to both reduce risks for individuals and risks within the marketing planning process. Of particular concern is the use of language by marketing professionals which can often be adversely misinterpreted by competition authorities. Indeed, this point is perhaps of even greater importance for the USA where juries, rather than appointed panels of 'experts', assess competitions cases. On this issue Crane (2005) indicates that a "... defendant's internal documents are often laced with aggressive or violent metaphors that sound shocking to jurors unfamiliar with the business world" leading to adverse findings in competition or antitrust cases. This situation is potentially compounded as the public perception of marketing is presently regarded as poor (Petty 2005).

Secondly, if marketing managers are a significant cause of competition law violations, it would be appropriate for these managers to have a greater role in demonstrating compliance with these laws. The question of who is responsible for compliance with competition law within the firm has yet to be systematically addressed within the academic literature. Similarly, the competition authorities 
might consider developing greater dialogue with marketing academics and managers with the aim of disseminating good practice and reducing competition violations. Further, the present shift towards including more academic economists and lawyers on UK competition authorities' decision-making bodies (Wilks 1999), rather than persons with a business background, may require reassessment.

Lastly, the overlap between marketing actions and competition law is clearly an area demanding much more marketing assessment, discussion and research. Initially, continued examination of competition judgements is required. Assessment of particular competition decisions, how these are made and the wider implications of such judgements is required to both develop greater awareness of competition law and to reduce future abuses. Equally, judgements viewed to have unclear or adverse effects on firms and consumers (see Kay and Sharpe 1982, Dobbin and Dowd 1997, 2000, Ashton and Keasey 2005, Mezias and Boyle 2005) require further critical investigation. Secondly, research which determines whom within the firm deals with competition law compliance is a key intermediate step when assessing why so many competition law violations are allowed to develop. Further, assessment of how marketers operating throughout the firm have adapted their behaviours to new competition law is also an underresearched topic. Lastly, greater engagement of marketing academics with contemporary and pertinent policy debates is required. This commitment may have many dimensions including an awareness of competition development, the costs of being viewed as uncompetitive and the fairness and transparency of competition law judgements. Indeed, rebuilding the past tradition of competition policy discussions in mainstream marketing is now long overdue. 


\section{References}

Aiginger, K., McCabe, M., Meueller, D. C., and Weiss, C. (2001). "Do American and European Industrial Organization Economists Differ?", Review of Industrial Organization, vol.19, pp. 283-405.

Ashton J. K. and Keasey, K. (2005). "Competition and the Provision of Banking Services to UK SMEs", Small Business Economics, vol.24, no.5,. pp.477-485.

Ashton J. K. and A. Pressey, (2004). "The Regulatory Challenge to Relationship Marketing in UK Banking", The International Journal of Bank Marketing, vol.22, no.6, pp.453-464.

Baer, W. J. (1996). "Surf's Up: Antitrust Enforcement and Consumer Interest in a Merger Wave”, The Journal of Consumer Affairs, vol.30, no.2, pp.292-321.

Blattberg, R. C. and Deighton, J. (1991). "Interactive Marketing - Exploiting the age of addressability", Sloan Management Review, vol.33, no.1, pp.5-14.

Bush, D. and Gelb, B. D. (2005). "When Marketing Practices Raise Antitrust Concerns", MIT Sloan Management Review, Summer, pp.73-81.

Caswell, J. A., Ning, Y. M., Liu, F., and Mojduszka, E. M. (2003). "The impact of new labeling regulations on the use of voluntary nutrient-content and health claims by food manufacturers", Journal of Public Policy and Marketing, vol. 22, no. 2, pp. 147-158.

Competition Commission (2003). Market Investigation References: Competition Commission Guidelines, Competition Commission, London.

Competition Commission (various). Competition Investigations, Competition Commission, London.

Crane, D. A. (2005). "The Paradox of Predatory Pricing", Cornell Law Review, vol.91, no.1, pp.1-66.

Czinkota, M. R. (2000). "The Policy Gap in International Marketing", Journal of International Marketing, vol.8, no.1, pp.99-111.

Davies, S. W., Driffield, N. L. and Clarke, R. (1999). "Monopoly in the UK: What Determines Whether The MMC Finds Against the Investigated Firms?", The Journal of Industrial Economics, vol.47, no.3, pp.263-283.

Day. G. S. (2000). "Managing Market Relationships", Journal of the Academy of Marketing Science, vol.28, no.1, pp.24-30. 
Djelic. M. L. (2002). "Does Europe mean Americanization? The Case of Competition" Competition and Change, vol.6, no.3, pp. 223-250.

Dobbin, F. and Dowd, T. (2000). "The Market Antitrust Built: Public Policy Private Coercion and Railroad Acquisitions, 1825-1922", American Sociological Review, vol.65, pp. 631-657.

Dobbin, F. and Dowd, T. (1997). "How Policy Shapes Competition: Early railroad founding in Massachusetts", Administrative Science Quarterly, vol.42, pp.501529.

Dolan R. J. (1987). "Quantity Discounts - Managerial Issues and Research Opportunities", Marketing Science, vol.6, no.1, pp. 1-22.

Edwards, C. D. (1950). "Trends in the Enforcement of the Antimonopoly Laws", Journal of Marketing, vol.15, no.5, pp.657- 665.

Engle, N. H. (1936). "Implications of the Robinson-Patman Act for Marketing", Journal of Marketing, vol.1, No.2, pp.75-81.

Fitchett, J. A., and McDonagh, P., (2000). "A Citizen's Critique of Relationship Marketing in Risk Society", Journal of Strategic Marketing, vol.8, no.2, pp.209222.

Fontenot, R. J. and Hyman, M. R. (2004). "The Antitrust Implications of Relationship Marketing", Journal of Business Research, vol.57, no.11, pp.12111221.

Ghosal, V. and Gallo, J. (2001). The cyclical behaviour of the Department of Justice's antitrust enforcement activity", International Journal of Industrial Organization, vol.19, pp.27-54.

Good, D. J., and Evans, K. R., (2001). "Relationship Unrest - A Strategic Perspective for Business-to-Business Marketers", European Journal of Marketing, vol.35, no.5/6, pp.549-565.

Gundlach, G. T. (1996). "Exchange relationships and the efficiency interests of the law", Journal of Public Policy and Marketing, vol.15, no. 2, pp.185-202.

Gundlach, G. T. and Phillips, J. M. (2002). "Marketing in Antitrust: Contributions and Challenges", Journal of Public Policy and Marketing, vol.21, no.2, pp.250253.

Howard, J. A (1950). "New British Law on Monopoly", Journal of Marketing, vol.14, no.4, pp.590-594. 
Hoek, J. and Sparks, R. (2000). Tobacco promotion Restrictions. An international regulatory impasses?", International Marketing Review, vol.17, No.3, pp.216-230.

Howe, M., (1979). "Pickering on Recommended Prices: A Comment on his Paper", Journal of Consumer Policy, vol.3, no.1, pp.81-85.

Jennings, P. D., Schulz, M., Patient. D., Gravel, C., and Yuan, K. (2005). "Weber and Legal Evolution: The Closing of the Iron Cage", Organizational Studies, vol.26, no.4, pp.621-653.

Kay, J. A., and Sharpe, T. A. E., (1982). "The Anti-Competitive Practice", Fiscal Studies, vol.3, no.3, pp.191-198.

Le Clair, D. T. (2000). "Marketing planning and the policy environment in the European Union", International Marketing Review, vol.17, no.3, pp.193-215.

Le Clair, D. T., Ferrell, O. C. and Ferrell, L. (1997). "Federal Sentencing Guidelines for Organizations: Legal, Ethical and Public Policy Issues for International Marketing, Journal of Public Policy and Marketing, vol.16, no.1, pp.26-37.

Lewis-Beck, M. S. (1979). "Maintaining Economic Competition: The Causes and Consequences of Antitrust", Journal of Politics, vol.41, pp. 169-191.

Lovelock, C. J., (1991). "Services Marketing", Prentice Hall: New Jersey.

McAlister, D.T. and Erffmeyer, R. C. (2003). "A content analysis of outcomes and responsibilities for consumer complaints to third-party organizations" Journal of Business Research, vol. 56, no. 4, pp. 341-351.

McCorriston, S. and Sheldon, I. M. (1997). "The (non-)equivalence of tariffs and quantity restraints as 'rent-shifting' policies", Canadian Journal of Economics, vol. 30, no. 4, pp.1220-1233.

McNair, M. P. (1938). "Fair Trade Legislation and the Retailer", Journal of Marketing, vol.2, no.4, pp.295-300.

Mezias, S. J. and Boyle, E. (2005). "Blind Trust: Market Control, Legal Environments, and the Dynamics of Competitive Intensity in the Early American Film Industry, 1893 - 1920.", Administrative Science Quarterly, vol.50, pp 1-34.

Nason, R. W. and Della Bitta, A. J. (1983). "The Incidence and Consumer Perceptions of Quantity Surcharges", Journal of Retailing, vol. 59, no.2, pp. 4054. 
Nystrom, P. H. (1936). "Legislative Trends of Interest to Students of Marketing", Journal of Marketing, vol.1, no.2, pp.154-155.

Office of Fair Trading, (2004). Assessment of Conduct. Draft Competition law Guidelines for Consultation, Office of Fair Trading, London.

Office of Fair Trading, (2005). Competing Fairly. An introduction to the laws on anti-competitive behaviour, Office of Fair Trading, London.

Petty R. D. (2005). "Societal Regulation of the Marketing Function: Does the Patchwork Create a Quilt", Journal of Public Policy and Marketing, vol.24, no.1, pp.63-74.

Petty R. D. (1999). "Editor's Introduction: The, What and Why of Marketing Law", American Business Law Journal, vol.36, pp.239-254.

Posner, R. A. (1970). "A Statistical Study of Antitrust Enforcement", Journal of Law and Economics, vol.13, pp.365-419.

Rao, A. (1980). "Quantity Discounts in Today's Markets", Journal of Marketing, vol.44, no.4, pp. 44-51.

Sharma, A. (2002). "Trends in Internet-based Business-to-Business Marketing", Industrial Marketing Management, vol. 31, no. 2, pp.77-84.

Sheth, J. N., and Sisodia, R. S. (1999). "Revisiting marketing's law like generalizations", Journal of the Academy of Marketing Science, vol. 27, no. 1, pp. 71-87.

Sheth, J. N., and Sharma, A., (1996). "Supplier Relationships - Emerging Issues and Challenges", Industrial Marketing Management, vol.26, no.2, pp.91-100.

Sheehan, K. B. (2003). "Balancing Acts: An Analysis of Food and Drug Administration Letters About Direct-to-Customer Advertising Violations", Journal of Public Policy and Marketing, vol.22, no.2, pp.159-169.

Stuyck, J. (2005). "EC Competition Law After Modernisation: More Than Ever in the Interest of Consumers", Journal of Consumer Policy, vol.28, pp.1-30.

Urbany, J. E. and Dickson, P.R. (1994). "Evidence on the risk-taking of price setters", Journal of Economic Psychology, vol. 15, no.1, pp. 127-148.

Weir, C. (1993). "Merger policy and competition: an analysis of the Monopolies and Mergers Commission's decisions", Applied Economics, vol. 25, no.1, pp. 5767. 
Weir, C. (1992). "Monopolies and Mergers Commission, merger reports and the public interest: a probit analysis" Applied Economics, vol. 24, no. 1, pp.27-35.

Wilkie, W. L and E. S. Moore, (1999). "Marketing's Contribution to Society", Journal of Marketing, vol.63, Special Issue, pp.198-218.

Wilcox, J. B., Howell, R. D., Kuzdrall, P. and Britney, R. (1987). "Price Quantity Discounts - Some implications for Buyers and Sellers", Journal of Marketing, vol.51, no.3, pp.60-70.

Wilks, S. (1999). In the Public Interest. Competition Policy and the Monopolies and Mergers Commission, Manchester University Press, Manchester, UK. 


\section{Appendix}

UK Competition Authority cases involving marketing by year and uncompetitive behaviour

\begin{tabular}{|c|c|c|c|c|c|c|}
\hline Time period & 1950-1959 & 1960-1969 & $1970-1979$ & 1980-1989 & 1990-1999 & 2000-2005 \\
\hline $\begin{array}{c}\text { Cases } \\
\text { involving } \\
\text { marketing and } \\
\text { excessive } \\
\text { prices }\end{array}$ & $\begin{array}{l}\text { Dental goods, Cast iron } \\
\text { rainwater goods, } \\
\text { Electric lamps, } \\
\text { Insulated electric wires } \\
\text { and cables, Imported } \\
\text { timber, Pneumatic } \\
\text { tyres, Sand and gravel } \\
\text { in Central Scotland, } \\
\text { Hard fibre cordage, } \\
\text { Rubber footwear, } \\
\text { Linoleum, Electronic } \\
\text { valves and cathode ray } \\
\text { tubes. }\end{array}$ & $\begin{array}{c}\text { Electrical } \\
\text { equipment for } \\
\text { mechanically } \\
\text { propelled land } \\
\text { vehicles, Petrol to } \\
\text { retailers, Electric } \\
\text { lamps (Parts I and } \\
\text { II)* }\end{array}$ & $\begin{array}{l}\text { Metal containers, } \\
\text { Asbestos and } \\
\text { certain Asbestos } \\
\text { Products, } \\
\text { Breakfast } \\
\text { cereals*, } \\
\text { Chlordiazepoxide } \\
\text { and Diazepam†, } \\
\text { Ice Cream and } \\
\text { Water lces. }\end{array}$ & $\begin{array}{c}\text { Tampons }{ }^{\star} \dagger(1980), \\
\text { Tampons (1988), } \\
\text { Liquefied Petroleum } \\
\text { Gas†, Concrete Roofing } \\
\text { Tiles, Bicycles, Car Parts, } \\
\text { British Broadcasting } \\
\text { Corporation and } \\
\text { Independent Television } \\
\text { Publications, Steel Wire } \\
\text { Fencing, Marine Radio } \\
\text { Navigation Receivers†, } \\
\text { Specialised Advertising } \\
\text { Services, Chatline and } \\
\text { Message Services†, Civil } \\
\text { Engineering Consultancy } \\
\text { Services, Black \& } \\
\text { Decker†. }\end{array}$ & $\begin{array}{l}\text { Carbonated drinks, } \\
\text { Car parts, New } \\
\text { cars, Fine } \\
\text { fragrances, Films, } \\
\text { Video Games, } \\
\text { Domestic electrical } \\
\text { goods (Parts I \& } \\
\text { II), Foreign } \\
\text { package holidays. }\end{array}$ & $\begin{array}{l}\text { The supply of impulse } \\
\text { ice cream, New Cars, } \\
\text { Supermarkets }{ }^{\star} \text {, Banking } \\
\text { services by clearing } \\
\text { banks to small and } \\
\text { medium-sized } \\
\text { enterprises*, Veterinary } \\
\text { Medicines (Parts } 1 \& 2 \text { ). }\end{array}$ \\
\hline $\begin{array}{c}\text { Cases } \\
\text { involving } \\
\text { marketing and } \\
\text { price } \\
\text { discrimination }\end{array}$ & $\begin{array}{l}\text { Hard fibre cordage } \\
\text { Electronic valves and } \\
\text { cathode ray tubes. }\end{array}$ & $\begin{array}{c}\text { Electrical } \\
\text { equipment for } \\
\text { mechanically } \\
\text { propelled land } \\
\text { vehicles. }\end{array}$ & $\begin{array}{l}\text { Fire Insurance, } \\
\text { Building Bricks. }\end{array}$ & (2) & Video Games*. & $\begin{array}{c}\text { Supermarkets, } \\
\text { Veterinary Medicines. }\end{array}$ \\
\hline $\begin{array}{c}\text { Cases } \\
\text { involving } \\
\text { marketing and } \\
\text { predation }\end{array}$ & $\begin{array}{l}\text { Electronic valves and } \\
\text { cathode ray tubes. }\end{array}$ & ------- & $\begin{array}{c}\text { Accountancy } \\
\text { Servicest, Ice } \\
\text { Cream and Water } \\
\text { Ices. }\end{array}$ & $\begin{array}{l}\text { The British Broadcasting } \\
\text { Corporation and } \\
\text { Independent Television } \\
\text { Publications }\end{array}$ & ------- & Supermarkets* \\
\hline
\end{tabular}

* indicates case mentioned in the analysis (section 4)

$\dagger$ indicates marketing specifically mentioned within the report as a competition concern. 
UK Competition Authority cases involving marketing by year and uncompetitive behaviour (continued)

\begin{tabular}{|c|c|c|c|c|c|c|}
\hline Time period & 1950-1959 & $1960-1969$ & $1970-1979$ & $1980-1989$ & 1990-1999 & $2000-2005$ \\
\hline $\begin{array}{c}\text { Cases } \\
\text { involving } \\
\text { marketing and } \\
\text { discounts }\end{array}$ & $\begin{array}{l}\text { Dental goods, Cast } \\
\text { iron rainwater goods, } \\
\text { Electric lamps, } \\
\text { Insulated electric wires } \\
\text { and cables, Copper } \\
\text { products* }{ }^{*} \text { Hard fibre } \\
\text { cordage }^{*} \text { Linoleum, } \\
\text { Electronic valves and } \\
\text { cathode ray tubes. }\end{array}$ & $\begin{array}{l}\text { Cigarettes and } \\
\text { tobacco, Electrical } \\
\text { equipment for } \\
\text { mechanically } \\
\text { propelled land } \\
\text { vehicles. }\end{array}$ & $\begin{array}{l}\text { Metal Containers, } \\
\text { Footwear } \\
\text { Machinery, Frozen } \\
\text { Foodstuffs*, Diazo } \\
\text { Copying Materials, } \\
\text { Petrol, Ice Cream } \\
\text { and Water Ices. }\end{array}$ & $\begin{array}{c}\text { Domestic Gas } \\
\text { Appliances, Foreign } \\
\text { Package Holidays, Steel } \\
\text { Wire Fencing. }\end{array}$ & $\begin{array}{l}\text { Tambrands Ltd*, } \\
\text { Domestic } \\
\text { electrical goods } \\
\text { (Parts I \& II), } \\
\text { Foreign package } \\
\text { holidays. }\end{array}$ & $\begin{array}{l}\text { The supply of impulse } \\
\text { ice cream, New Cars, } \\
\text { Veterinary Medicines } \\
\text { (Parts } 1 \& 2) \text {. }\end{array}$ \\
\hline $\begin{array}{c}\text { Cases } \\
\text { involving } \\
\text { marketing and } \\
\text { vertical } \\
\text { restraints }\end{array}$ & $\begin{array}{l}\text { Dental goods*, Cast } \\
\text { iron rainwater goods, } \\
\text { Electric lamps*, } \\
\text { Insulated electric wires } \\
\text { and cables, Insulin, } \\
\text { Matches and match- } \\
\text { making machinery, } \\
\text { Imported timber, } \\
\text { Buildings in the } \\
\text { Greater London area, } \\
\text { Copper products, } \\
\text { Pneumatic tyres, Sand } \\
\text { and gravel in Central } \\
\text { Scotland, Hard fibre } \\
\text { cordage*, Rubber } \\
\text { footwear, Linoleum, } \\
\text { Industrial and medical } \\
\text { gases*, Electronic } \\
\text { valves and cathode } \\
\text { ray tubes, Electrical } \\
\text { and allied machinery } \\
\text { and plant. }\end{array}$ & $\begin{array}{c}\text { Electrical } \\
\text { equipment for } \\
\text { mechanically } \\
\text { propelled land } \\
\text { vehicles, Petrol to } \\
\text { retailers*, Electric } \\
\text { Lamps (Parts I \& }^{\star} \\
\text { II)*. }\end{array}$ & $\begin{array}{l}\text { Metal Containers, } \\
\text { Fire Insurance, } \\
\text { Asbestos and } \\
\text { certain Asbestos } \\
\text { Products, Primary } \\
\text { Batteries, Barristers' } \\
\text { Services, Services } \\
\text { of Solicitors in } \\
\text { England and Wales, } \\
\text { Services of Solicitors } \\
\text { in Scotland, } \\
\text { Accountancy } \\
\text { Servicest, } \\
\text { Stockbrokers' } \\
\text { Services†, } \\
\text { Veterinary } \\
\text { Servicest, Frozen } \\
\text { Foodstuffs, Indirect } \\
\text { Electrostatic } \\
\text { Reprographic } \\
\text { Equipment, } \\
\text { Wholesaling of } \\
\text { Newspapers and } \\
\text { Periodicals, Petrol }{ }^{\star} \text {, } \\
\text { Electricity Supply } \\
\text { Meters, Ice Cream } \\
\text { and Water Ices*. }\end{array}$ & $\begin{array}{c}\text { Domestic Gas } \\
\text { Appliances*, Liquefied } \\
\text { Petroleum Gas* }{ }^{*}, \\
\text { Roadside Advertising } \\
\text { Services, Concrete } \\
\text { Roofing Tiles, Bicycles, } \\
\text { Car Parts*, Holiday } \\
\text { Caravan Sites in } \\
\text { Northern Ireland, The } \\
\text { British Broadcasting } \\
\text { Corporation and } \\
\text { Independent Television } \\
\text { Publications, Foreign } \\
\text { Package Holidays*, } \\
\text { Steel Wire Fencing, } \\
\text { Marine Radio Navigation } \\
\text { Receivers†, Specialised } \\
\text { Advertising Services, } \\
\text { Chatline and Message } \\
\text { Services†, Civil } \\
\text { Engineering Consultancy } \\
\text { Services, Black \& } \\
\text { Deckert. }\end{array}$ & $\begin{array}{c}\text { Carbonated } \\
\text { drinks*, Car parts, } \\
\text { New cars, Fine } \\
\text { fragrances, Films, } \\
\text { Tambrands Ltd, } \\
\text { Domestic } \\
\text { electrical goods } \\
\text { (Parts I \& II), } \\
\text { Foreign package } \\
\text { holidays*. }\end{array}$ & $\begin{array}{l}\text { The supply of impulse } \\
\text { ice cream }{ }^{\star} \text {, New Cars, } \\
\text { Supermarkets*, The } \\
\text { supply of banking } \\
\text { services by clearing } \\
\text { banks to small and } \\
\text { medium-sized } \\
\text { enterprises, Veterinary } \\
\text { Medicines (Parts } 1 \& 2 \text { ). }\end{array}$ \\
\hline
\end{tabular}

* indicates case mentioned in the analysis (section 4)

$\dagger$ indicates marketing specifically mentioned within the report as a competition concern. 
UK Competition Authority cases involving marketing by year and uncompetitive behaviour (continued)

\begin{tabular}{|c|c|c|c|c|c|c|}
\hline Time period & $1950-1959$ & $1960-1969$ & $1970-1979$ & $1980-1989$ & 1990-1999 & $2000-2005$ \\
\hline $\begin{array}{l}\text { Cases } \\
\text { involving } \\
\text { marketing and } \\
\text { supply } \\
\text { refusal }\end{array}$ & $\begin{array}{l}\text { Dental goods, Cast } \\
\text { iron rainwater goods, } \\
\text { Electric lamps, } \\
\text { Insulated electric wires } \\
\text { and cables, Insulin, } \\
\text { Imported timber, } \\
\text { Buildings in the } \\
\text { Greater London area, } \\
\text { Copper products, } \\
\text { Pneumatic tyres, Sand } \\
\text { and gravel in Central } \\
\text { Scotland, Hard fibre } \\
\text { cordage, Rubber } \\
\text { footwear, Industrial } \\
\text { and medical gases, } \\
\text { Chemical fertilisers. }\end{array}$ & $\begin{array}{c}\text { Cigarettes and } \\
\text { tobacco, Electrical } \\
\text { equipment for } \\
\text { mechanically } \\
\text { propelled land } \\
\text { vehicles, Petrol, } \\
\text { Household } \\
\text { Detergents†, Man- } \\
\text { Made Cellulosic } \\
\text { Fibres, Electric } \\
\text { Lamps (Parts } 1 \text { \& } \\
\text { 2). }\end{array}$ & $\begin{array}{l}\text { Metal Containers, } \\
\text { Fire Insurance, } \\
\text { Breakfast Cereals, } \\
\text { Chlordiazepoxide } \\
\text { and Diazepam, } \\
\text { Footwear } \\
\text { Machinery, Primary } \\
\text { Batteries, } \\
\text { Contraceptive } \\
\text { Sheaths, Building } \\
\text { Bricks, Advocates' } \\
\text { Services, Barristers' } \\
\text { Services, Services } \\
\text { of Solicitors in } \\
\text { England and Wales, } \\
\text { Services of Solicitors } \\
\text { in Scotland, } \\
\text { Accountancy } \\
\text { Servicest, } \\
\text { Stockbrokers' } \\
\text { Services†, } \\
\text { Veterinary Service†, } \\
\text { Frozen Foodstuffs, } \\
\text { Indirect Electrostatic } \\
\text { Reprographic } \\
\text { Equipment, Diazo } \\
\text { Copying Materials, } \\
\text { Cat and Dog Food†, } \\
\text { Petrol, Electricity } \\
\text { Supply Meters, Ice } \\
\text { Cream and Water } \\
\text { Ices. }\end{array}$ & $\begin{array}{c}\text { Tampons † (1980), } \\
\text { Tampons (1988), } \\
\text { Liquefied Petroleum } \\
\text { Gas†, Roadside } \\
\text { Advertising Services, } \\
\text { Concrete Roofing Tiles, } \\
\text { Bicycles*, Car Parts, } \\
\text { Holiday Caravan Sites in } \\
\text { Northern Ireland, The } \\
\text { British Broadcasting } \\
\text { Corporation and } \\
\text { Independent Television } \\
\text { Publications, Postal } \\
\text { Franking Machines, } \\
\text { Foreign Package } \\
\text { Holidays, Steel Wire } \\
\text { Fencing, Marine Radio } \\
\text { Navigation Receivers†, } \\
\text { Specialised Advertising } \\
\text { Services, Chatline and } \\
\text { Message Services†, Civil } \\
\text { Engineering Consultancy } \\
\text { Services, Services of } \\
\text { Medical Practitioners, } \\
\text { Black \& Decker†*. }\end{array}$ & $\begin{array}{c}\text { Petrol, Soluble } \\
\text { coffee, } \\
\text { Carbonated } \\
\text { drinks, Car parts, } \\
\text { New cars*, } \\
\text { Matches and } \\
\text { disposable } \\
\text { lighters, Fine } \\
\text { fragrances*, Films, } \\
\text { Video Games, } \\
\text { Bus services in } \\
\text { the north-east of } \\
\text { England, } \\
\text { Tambrands Ltd, } \\
\text { Domestic } \\
\text { electrical goods } \\
\text { (Parts I \& II)*, } \\
\text { Foreign package } \\
\text { holidays, Supply } \\
\text { of Raw Milk. }\end{array}$ & $\begin{array}{l}\text { The supply of impulse } \\
\text { ice cream, } \\
\text { Supermarkets, The } \\
\text { supply of banking } \\
\text { services by clearing } \\
\text { banks to small and } \\
\text { medium-sized } \\
\text { enterprises, Extended } \\
\text { warranties on domestic } \\
\text { electrical goods†. }\end{array}$ \\
\hline
\end{tabular}

* indicates case mentioned in the analysis (section 4)

$\dagger$ indicates marketing specifically mentioned within the report as a competition concern. 